\title{
Analysis of NPL in the Republic of Serbia and Selected Countries of South-Western Balkans
}

\author{
Vera Zelenovic, Jelena Vitomir \\ University of Novi Sad, Novi Sad, Serbia \\ Milan Radovic \\ Nova Banka AD Banja Luka, Banja Luka, Bosnia and Herzegovina
}

\begin{abstract}
The research problem addressed in this paper is whether the entry of an economy in crisis leads to the growth of percentage share of non-performing loans in total loans of the banking sector, as well as whether in this case the corporate sector and the retail sector are equally risky in terms of loans. The goal of this paper, on the basis of the analysis of non-performing loans in the banking systems of the Republic of Serbia and selected countries of South-Western Balkans, as well as their comparison, is to determine the existence of a causal link among the decline in economic activity, unemployment, and growth of non-performing loans, due to the fact that the bad loan portfolio is one of the most important factors of instability of banks and of the banking system as a whole, and as such, it produces negative effects on the overall economic activity of the country. Concluding observations are given below.
\end{abstract}

Keywords: bank, non-performing loans, banking systems, economy

Bad debts can be defined in different ways. Thus, the narrower definition of bad debts refers to those loans that do not yield an income and where it is impossible to expect full repayment of principal and interest in the future, as well as loans where the repayment of principal or interest is in arrears of 90 days or more, or loans where the maturity date is due or payment is not made in full.

The level of non-performing loans (NPLs) points to the problems faced by the economy of a country and its real sector, which is unable to repay the debt. Also, the level of NPLs may point out the poor regulatory judicial framework, therefore the resolution of NPLs issue requires a systematic approach. The main risk to a bank's asset quality is precisely the decline in overall economic activity, but this is not a strong enough explanatory factor of the movement of NPLs between countries and over time. The depreciation of the exchange rate is the main driver of NPLs in those countries that are characterized by a high level of loans granted in foreign currency. The practice indicates that an increase in lending interest rates leads to an increase of NPLs in the future (Zelenovic \& Macut, 2016).

Corresponding author: Vera Zelenovic, Ph.D., associate professor, Department of Finance, Banking, Accounting and Auditing, Faculty of Economics Subotica, University of Novi Sad, Novi Sad, Serbia; research fields: banking and banking marketing.

Jelena Vitomir, Ph.D., research fellow, Department of Finance, Banking, Accounting and Auditing, Faculty of Economics Subotica, University of Novi Sad, Novi Sad, Serbia; research field: banking.

Milan Radovic, Ph.D., assistant professor and CEO of Nova Banka AD Banja Luka, Banja Luka, Bosnia and Herzegovina; research field: banking. 
Given the fact that data on NPLs are often analyzed and compared in the countries of Europe and the world, it is very important to establish a harmonized system of their definition. Unfortunately, there is still no single definition of NPLs, which would be applied by all countries in evaluating the quality of assets in their banking systems. As a result of the lack of harmonized rules in this area, there is a constant concern regarding the consistency of evaluating banks' asset quality and its correct classification, especially when it comes to distinguishing regular from NPLs, as well as presenting provisions for this purpose. Although there is no generally accepted standard for defining NPLs, it can be concluded that in practice most countries apply a limit of 90 days or more past due as a criterion and they present the full amount of loans in default as NPLs. Some countries, with their definitions, do not fit the definition of NPLs set forth by the IMF (International Monetary Fund). Thus, certain countries consider all loans that are in arrears of 31 days or more, or 61 days or more as NPLs. Number of days in arrears is not the only criterion for different definitions of NPLs between countries. Among other elements, we should single out, for example, Romania, which for loan classification uses criterion of financial ability of the borrower and the fact whether the process of judicial execution has been initiated. Also, an important element of the definition of NPLs is whether they are presented in gross amount, which is the internationally accepted standard, or it is a net amount. A separate issue is how to classify multiple loans of the same client. In some countries, if a loan is classified as an NPL, then all other loans of the same client are classified in the same way. An interesting issue is the issue of the treatment and the role of collateral and guarantees in the process of classification. Certain jurisdictions do not consider collateral and guarantees for the purposes of classifying a loan into regular or NPL portfolio (Barisitz, 2011).

\section{Theory}

According to the IMF definition, NPL is a loan in which (Mirkovic, 2013):

(1) The borrower is late in repayment of principal or interest 90 days or more;

(2) The interest for the delay longer than 90 days is refinanced, capitalized, or its payment is deferred;

(3) The borrower is late less than 90 days, but the bank has estimated that the borrower's ability to repay the debt is worsened and that the debt repayment is brought into question.

According to the Decision on Classification of Bank Balance Sheet Assets and Off-balance Sheet Items, banks in the Republic of Serbia are obliged to classify all claims from a borrower, apart from claims specifically excepted by the Decision, in categories A, B, V, G, and D-based on the criterion of timeliness, i.e. delay in the settlement of that borrower's obligations to the bank, on the basis of the assessment of the borrower's financial position, i.e. creditworthiness, and on the basis of the quality of collateral. Claims from borrowers are classified as follows ("Decision on Classification of Bank Balance Sheet Assets and Off-balance Sheet Items"):

(1) Category A:

(a) Claims from the borrower with whom, on the basis of the assessment of the financial position, i.e. creditworthiness, no problems in the collection are expected;

(b) Claims secured by prime collateral;

(c) Claims for which the borrower settles the obligations on time or is in arrears no longer than 30 days;

(2) Category B:

(a) Claims from the borrower whose financial position, i.e. creditworthiness is not entirely satisfactory because of certain problems but does not indicate a significant deterioration in the future; 
(b) Claims for which the borrower is in arrears between 31 and 60 days;

(3) Category V:

(a) Claims from the borrower whose financial position, i.e. creditworthiness is not satisfactory and indicates the deterioration in the future;

(b) Claims for which the borrower is in arrears between 61 and 90 days;

(4) Category G:

(a) Claims from the borrower whose financial position, i.e. creditworthiness indicates significant problems in the ability to collect these claims, especially claims from an illiquid or insolvent borrower;

(b) Claims for which the borrower is in arrears between 91 and 180 days;

(5) Category D:

(a) Claims with doubtful or disputable legal basis;

(b) Claims from the borrower in liquidation or bankruptcy;

(c) Claims from the borrower who does not act in accordance with the adopted plan of reorganization in terms of the law governing the bankruptcy;

(d) Claims from the borrower- the newly established company, to which the bank has assigned claims;

(e) Claims for which the borrower is in arrears longer than 180 days;

(f) Claims that are not eligible for classification in other categories from this point;

(g) Claims from the borrower who had matured claims in the bank, which were assigned in the last three years.

When it comes to the Republic of Serbia, all claims arising from loans can be classified in categories V, G, and D.

One of the obvious consequences of the financial crisis is the instability of the financial sector, which significantly slows down the efforts for economic recovery and exits from the recession that began in 2008 in most economies of the world. An additional problem that occurs in NPLs is the presence of the so-called Rebound Effect (NPLs $\rightarrow$ economy), which is reflected in the further deterioration of economic activity: An increase of NPLs weakens macroeconomic performance of the economy, thus activating the "vicious circle" in which the problems of the banking sector and the decline in economic activity mutually reinforce each other. It is common that banking crises are associated with a high share of NPLs in the total assets of the banking sector. Factors influencing the level of NPLs can be divided into groups of macroeconomic factors and factors at the level of the banking sector (Klein, 2013). Grouped by categories, factors that influence the creation of the banking system instability and lead to crises in the banking system are (Mirkovic, 2013):

(1) Microeconomic factors - the presence of the principal-agent problem is significant, because if the loan officers are motivated by achieving high bonuses for the sake of realizing loan placements, they do not pay enough attention to the riskiness of the loans, which increases the exposure of banks to risks. These factors are very important, in addition to insufficiently good regulation in the banking sector, inadequate assessment of credit risks, and inadequate maturity match between assets and liabilities.

(2) Macroeconomic factors - come to the fore in developing countries because they are faced with much greater volatility in the macroeconomic area than developed countries. It is essential that the banking system is prepared for cyclical economic trends, depreciation of the exchange rate, a drop in the prices of assets, and similar phenomena. Despite all the measures taken, it is possible that some extra sudden shocks appear and will make an impact on the reluctance of the banking system and its adequate reaction at a given moment. 
(3) System solutions - the banking system does not operate in isolation from the overall economic system. Stability of the banking system may be compromised by inefficient operations of large state-owned banks, the banks in which the state is the single largest (but not the majority) shareholder, as well as inadequate legal regulations and supervisory regime over the banking system.

Financing of the fiscal deficit of the country by the banks could affect the growth of NPLs. Namely, financing of the fiscal deficit by banks may lead to reduced possibility for businesses and citizens to obtain new loans or refinance old loans, causing a growth in non-collectability of their loans. This is the so-called "crowding out" of businesses and citizens by the state (crowding out effect).

\section{Methods}

The research subject of this paper are NPLs in the banking systems of the Republic of Serbia and selected countries in the region of South-Western Balkans, their dynamics, sectorial structure, and the basic determinants of growth. The research goal is to point out the existence of a link among the decline in economic activity, unemployment, and growth of NPLs, due to the fact that the bad loan portfolio is one of the most important factors of instability of banks and the banking system as a whole, and as such, it produces negative effects on the overall economic activity of the country.

For research purposes, we used a method of analysis and synthesis of the contents of official publications of central banks of the countries analyzed, as well as statistical methods, and correlation analysis.

\section{Findings}

The banking sector in the Republic of Serbia is highly capitalized and liquid, but the situation is not idyllic. Every fifth of total granted placements was treated as an NPL at the end of the third quarter, which was neither a good indicator of the Serbian banking sector nor a good indicator of the quality of credit portfolios of banks. Thanks to the full coverage of loans by regulatory provisions, the stability of the financial system has not been compromised yet but NPLs are certainly treated as a source of systemic risk.

The Republic of Serbia has entered the crisis with a relatively high share of NPLs in total gross loans (11.3\% at the end of 2008). The share of NPLs grew from year to year, so at the end of 2015, gross NPLs amounted to $21.6 \%$ of total approved gross loans. A smaller decline in the share of gross NPLs that was recorded at the end of 2012 compared to the end of 2011 (from 19\% to 18.6\%), was a consequence of the bankruptcy of Agrobank and Razvojna bank of Vojvodina, two large state-owned banks, and the write-off of a large amount of bad assets.

In the Republic of Serbia, credit expansion in the period from 2003 to 2008 was carried not only by a good performance and credible plans of clients and indications of economic growth, but also by a strong fight of newly established banks for greater market share. The specific reason for the strong credit expansion in the Republic of Serbia in the pre-crisis period was the level of indebtedness of businesses and citizens, which at the beginning of transition was very low - the previous hyperinflation and inflation devalued the old loans. In the fight for a bigger market share, when granting loans, the banks mainly relied on real estate collaterals while the business activities of clients were of secondary importance. The problem arose when the value of collaterals during the crisis period dropped significantly and the liquidity of the real estate market decreased. The following chart (see Figure 2) shows a comparative review of the NPL trend and GDP growth rate in the Republic of Serbia in the period 2008-2015. 


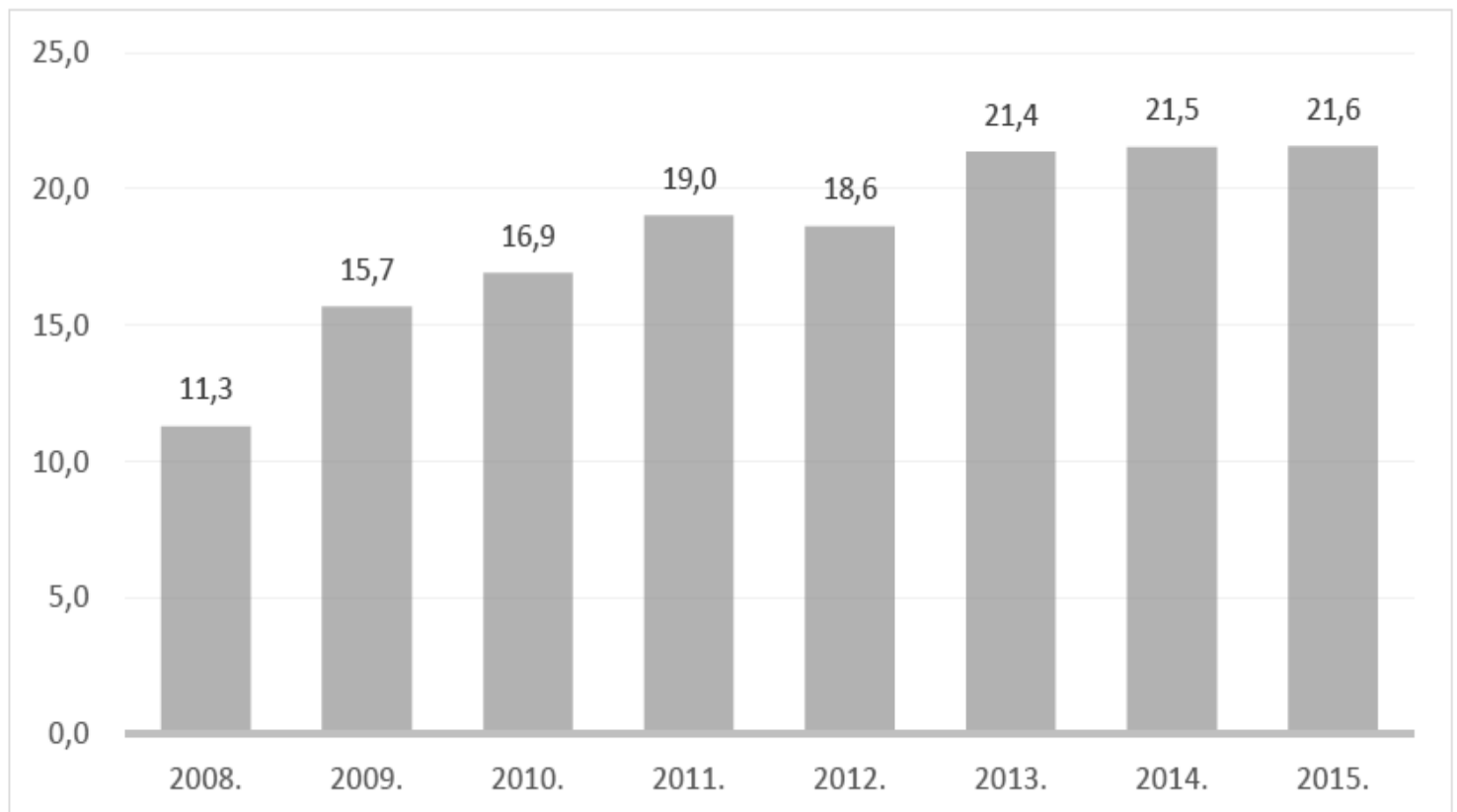

Figure 1. Percentage share of non-performing loans in total loans in the period 2008-2015. Source: Authors' review based on data from the NBS report, retrieved from http://www.nbs.rs.

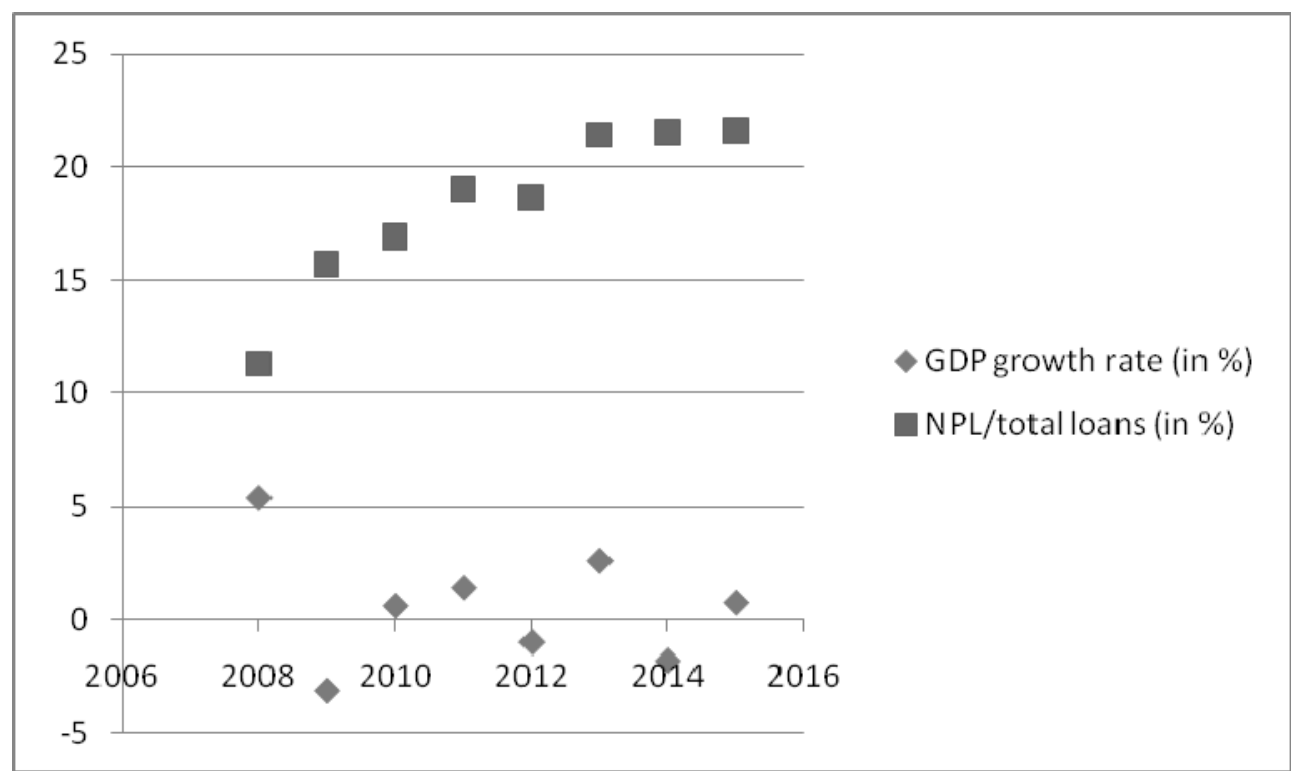

Figure 2. Comparative review of the NPL trend and GDP growth rate in Serbia in the period 2008-2015. Source: Authors' review based on data from the NBS report, retrieved from http://www.nbs.rs.

As can be seen in the previous chart (see Figure 1), the greatest increase in the share of NPLs in total gross loans in Serbia of $4.4 \%$ occurred in 2009 with the intensification of the financial crisis, which resulted in a sharp decline in economic activity and the realization of negative GDP growth rate of $-3.1 \%$. In the period after 2009, economic activity in the Republic of Serbia, one might say, stagnated with mutual alternation of phases of slight rise and fall, which along with the reduced level of lending by banks, to some extent affected the further increase of the share of NPLs. The exception was 2012, when there was a slight decrease in the share of NPLs by $0.4 \%$ (due to the bankruptcy of Agrobank and the Razvojna bank of Vojvodine and the 
write-off of a large amount of bad assets). What is very likely is that as long as there is no significant economic growth, there will be no significant changes in the share of NPLs, because economic growth also implies the growth of the borrower's capacity, i.e. ability to orderly settle obligations, and generally supports the financial stability.

Table 1

Comparative Table Review of the NPL Trend and GDP Growth Rate in Serbia in the Period 2008-2015

\begin{tabular}{lll}
\hline Year/ & Serbia & Serbia \\
Country & GDP growth rate (in \%) & NPL/total loans (in \%) \\
\hline 2008 & 5.4 & 11.3 \\
2009 & -3.1 & 15.7 \\
2010 & 0.6 & 16.9 \\
2011 & 1.4 & 19.0 \\
2012 & -1.0 & 18.6 \\
2013 & 2.6 & 21.4 \\
2014 & -1.8 & 21.5 \\
2015 & 0.74 & 21.6 \\
Pearson correlation coefficient & & -0.37455 \\
\hline
\end{tabular}

Note. Source: Authors' review based on data from the NBS report, retrieved from http://www.nbs.rs.

Parameters from the Figure 4 are also presented in Table 1, in order to calculate the Pearson correlation coefficient ${ }^{1}$. It is -0.37455 , medium correlation, while negative correlation indicates that an increase of value of one variable, in this case NPL, leads to the decrease of value of the other variable, in this case GDP.

Figure 3 presents comparative review of the NPL trend and unemployment rate in Serbia in the period 2008-2015 (in \%). The data in this figure are also presented in Table 2 in order to calculate the Pearson correlation coefficient.

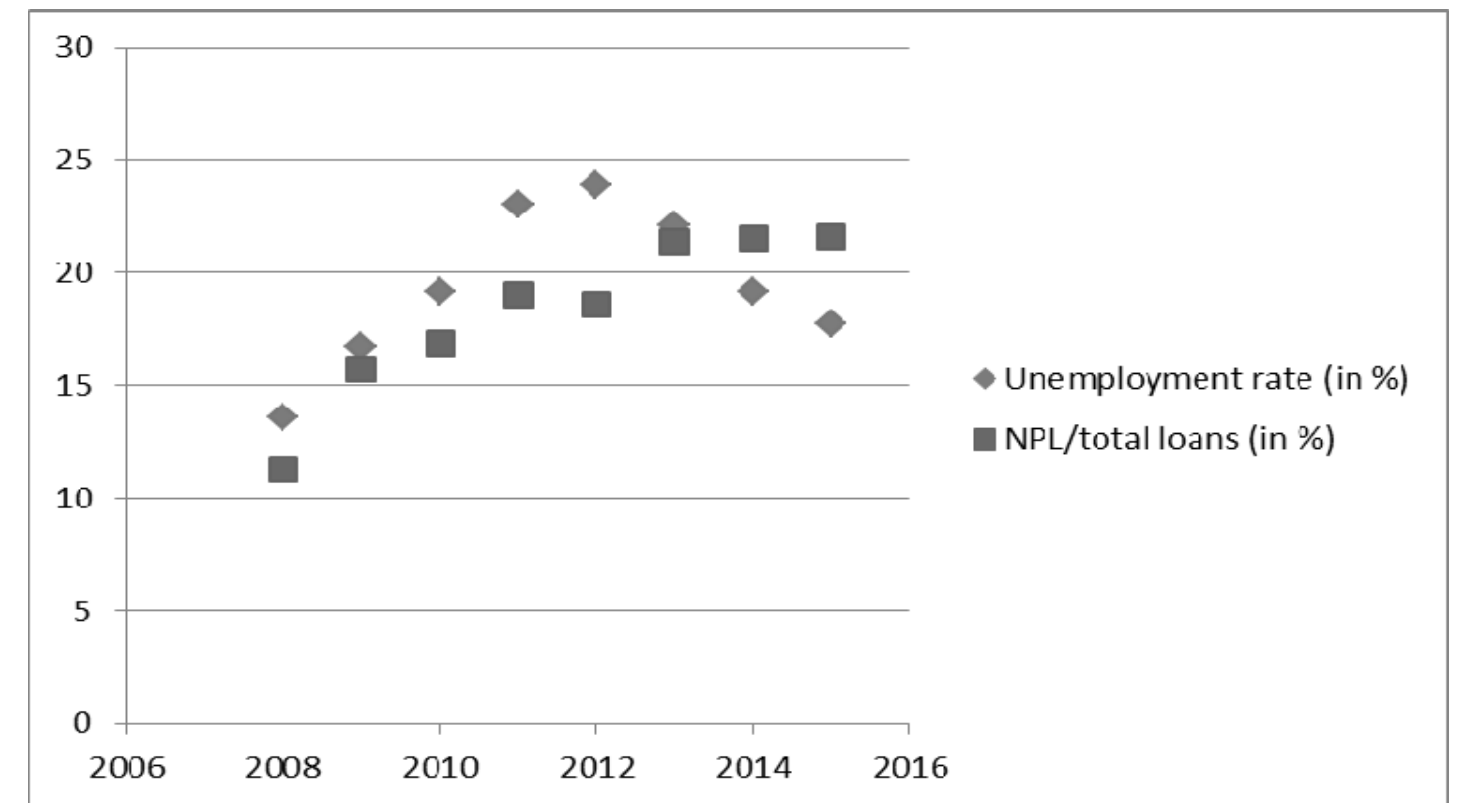

Figure 3. Comparative review of the NPL trend and unemployment rate in Serbia in the period 2008-2015 (in \%).

Source: National Bank of Serbia, retrieved from http://www.nbs.rs.

1 The coefficient is calculated using the Excel program. 
Table 2

Comparative Table Review of the NPL Trend and Unemployment Rate in Serbia in the Period 2008-2015

\begin{tabular}{lll}
\hline Year/ & Serbia & Serbia \\
Country & Unemployment rate (in \%) & NPL/total loans (in \%) \\
\hline 2008 & 13.6 & 11.3 \\
2009 & 16.7 & 15.7 \\
2010 & 19.2 & 16.9 \\
2011 & 23.0 & 19.0 \\
2012 & 23.9 & 18.6 \\
2013 & 22.1 & 21.4 \\
2014 & 19.2 & 21.5 \\
2015 & 17.7 & 21.6 \\
Pearson correlation coefficient & & 0.621851 \\
\hline
\end{tabular}

Note. Source: National Bank of Serbia, retrieved from http://www.nbs.rs.

The Pearson correlation coefficient was calculated from the above chart, i.e. Table 2, and it is 0.621851 . A positive, relatively strong correlation between the percentage of participation of NPLs in total gross loans and the unemployment rate is noticeable, which means that as the value of one variable (unemployment) grows, the value of other variable (NPL) also grows. The increase of the unemployment rate in the Republic of Serbia in the period after the outbreak of the financial crisis, consequently influenced the increase of the share of NPLs due to difficult possibilities of orderly settlement of obligations by the borrowers who lost their jobs in that period. The unemployment was and still is one of the biggest problems of the Serbian economy.

The high and growing level of NPLs represents a source of systemic risk, not only in the Republic of Serbia but also in other emerging countries, as well as in some developed countries. If NPLs reach certain level, they have a negative impact on the channels of loan offer and cause the deterioration of the banking sector indicators. Cleaning the balance sheets of the banking sector has become necessary for a new lending activity at lower interest rates and support to the economy in order to achieve sustainable economic growth rates. Analysis of international financial institutions suggests that an indicator of NPLs higher than $10 \%$ reduces the lending activity by $4 \%$, after excluding side effects. In Serbia, this indicator is at a significantly higher level in the last five years. Monitoring of indicators which point out the level and trend of NPLs is very important in terms of identifying potential problems in the collection of claims, as they warn of the deterioration of quality of the loan portfolio of the banking sector. NPLs represent a serious problem for the banking sector in Serbia, since there is a visible tendency of constant growth of NPLs in relation to the total disbursed loans (Zelenovic \& Macut, 2016).

The high level of NPLs has become a limiting factor during the crisis and has grown into a source of systemic risk, not only in Serbia but also in other developing countries. In addition, it limits the growth of lending and overall economic activity. Solving the issue of NPLs in Serbia progressed slowly. In order to preserve the stability of the banking sector, the National Bank of Serbia (NBS) has adopted several counter-cyclical regulatory measures, whose implementation was possible thanks to a substantial amount of reserves accumulated in the pre-crisis period ("Strategy for the Resolution of Non-Performing Loans"):

(1) By amending the Decision on Risk Management from December 2012, the banks were allowed to mitigate credit risk by assigning matured claims of one legal entity or entrepreneur to another legal entity. This is a key improvement since the assignment of claims was very strictly regulated before the adoption of amendments. 
(2) Amendments to the Decision on Classification of Bank Balance Sheet Assets and Off-balance Sheet Items from December 2012 also aimed to contribute to resolving the issue of NPLs, by encouraging banks to make further efforts in the implementation of existing legal mechanisms (e.g. Law on Voluntary Financial Restructuring, Bankruptcy Law).

(3) At the end of 2014, the Executive Board of NBS adopted the amendments to the Decision on Classification of Bank Balance Sheet Assets and Off-balance Sheet Items. The amendments refer to the rules of classification of assets acquired in debt collection, claims from persons to whom the claims have been assigned, as well as the calculation of the number of days of delay from the subsequently agreed maturity date.

Comparative analysis of the dynamics of NPLs in the banking systems of neighboring countries in the period 2008-2015, shows significant differences in the level of participation of NPLs in total loans granted by countries (see Figure 4). The Republic of Serbia has greatest share of NPLs in total disbursed loans at the end of the analyzed period with $21.60 \%$, followed by the Republic of Croatia with $16.65 \%$, and Bosnia and Herzegovina with $13.70 \%$, while the Republic of Macedonia has the lowest share of NPLs in total loans and it amounts to $10.30 \%$.

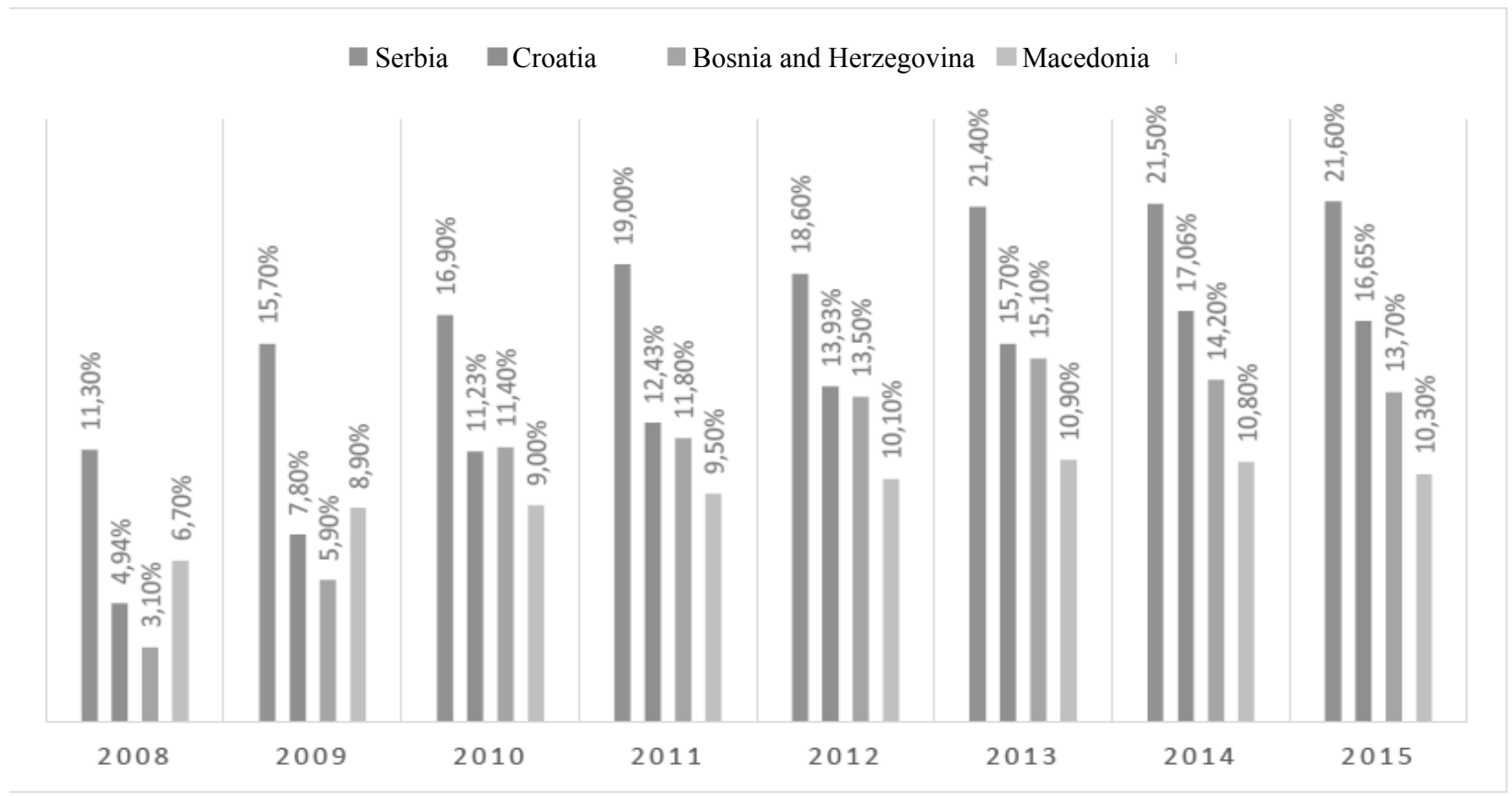

Figure 4. Comparative review of the share of non-performing loans in total disbursed loans in the banking systems of selected countries in the period 2008-2015. Source: Authors' review based on data taken from the websites of the central banks of analyzed countries.

What is evident from the previous chart is that only in the last two years of the observed period in all analyzed countries, except for Serbia, there was a decrease in the share of non-performing loans in total disbursed loans, but this reduction is not yet significant in scope.

In the Republic of Serbia, the percentage of NPLs in comparison to total loans is still extremely high and represents a continuing threat to the stability of the entire banking system. As indicated in the part of this paper relating to the Republic of Serbia, in 2015, the state authorities realized that without resolving the issue of NPLs, we could not talk about the growth of banks' lending activity, which is one of the most important 
preconditions for the growth of business, i.e. total economic activity. Such determination of the authorities in Serbia resulted in the adoption of comprehensive Strategy for the Resolution of Non-Performing Loans, which provided for significant structural and institutional improvements, as well as improvement of the capacity of banks to resolve NPLs. Over the next few years, implementation of planned activities should lead to gradual reduction of the share of NPLs in total loans and the final release of banks' balance sheets from "toxic" assets, which significantly burden their business activities. In the Republic of Croatia, the share of NPLs in total loans is also very high, and the problem resolution goes in the direction of sales of NPLs by banks to interested buyers, which are usually foreign investment funds. In Bosnia and Herzegovina, the participation of NPLs in total loans is not as high as it is in Serbia and Croatia, but still negatively affects the performance of the banking system. Previous measures to reduce the share of NPLs in total loans in Bosnia and Herzegovina related to the permanent write-off of NPLs and their transfer to separate legal entities. The state of NPLs in Macedonia is not as alarming and does not threaten to endanger the stability of the banking system. The reason for this is that Macedonia, before the outbreak of the financial crisis, did not have such a strong credit growth as it was the case in other analyzed countries.

In the conditions of recession and financial crisis, there is a growth in percentage share of NPLs in total loans of the banking sector, and they also have the influence on the trends of the real GDP rate.

Table 3

Comparative Review of GDP Rate Trend and Share of NPLs in Total Loans by Countries in the Period 2008-2015

\begin{tabular}{lllllllll}
\hline \multirow{2}{*}{$\begin{array}{l}\text { Year/ } \\
\text { Country }\end{array}$} & \multicolumn{3}{c}{ Serbia } & \multicolumn{2}{c}{ Croatia } & \multicolumn{2}{c}{ Macedonia } & \multicolumn{2}{c}{ Bosnia and Herzegovina } \\
& $\begin{array}{l}\text { GDP growth } \\
\text { rate } \text { (in })\end{array}$ & $\begin{array}{l}\text { NPL/total } \\
\text { loans (in \%) }\end{array}$ & $\begin{array}{l}\text { GDP growth } \\
\text { rate (in \%) }\end{array}$ & $\begin{array}{l}\text { NPL/total } \\
\text { loans (in \%) }\end{array}$ & $\begin{array}{l}\text { GDP growth } \\
\text { rate (in \%) }\end{array}$ & $\begin{array}{l}\text { NPL/total } \\
\text { loans (in \%) }\end{array}$ & $\begin{array}{l}\text { GDP growth } \\
\text { rate (in \%) }\end{array}$ & $\begin{array}{l}\text { NPL/total } \\
\text { loans (in \%) }\end{array}$ \\
\hline 2008 & 5.4 & 11.3 & 2.1 & 4.94 & 5.47 & 6.7 & 5.48 & 3.1 \\
2009 & -3.1 & 15.7 & -7.4 & 7.80 & -0.36 & 8.9 & -2.87 & 5.9 \\
2010 & 0.6 & 16.9 & -1.7 & 11.23 & 3.36 & 9.0 & 0.77 & 11.4 \\
2011 & 1.4 & 19.0 & -0.3 & 12.43 & 2.34 & 9.5 & 0.91 & 11.8 \\
2012 & -1.0 & 18.6 & -2.2 & 13.93 & -0.46 & 10.1 & -0.93 & 13.5 \\
2013 & 2.6 & 21.4 & -1.1 & 15.70 & 2.93 & 10.9 & 2.39 & 15.1 \\
2014 & -1.8 & 21.5 & -0.4 & 17.06 & 3.54 & 10.8 & 1.08 & 14.2 \\
2015 & 0.74 & 21.6 & 1.6 & 16.65 & 3.67 & 10.3 & 3.16 & 13.7 \\
\hline
\end{tabular}

Note. Source: Authors' review based on data taken from the websites of the central banks of analyzed countries.

Based on the presented data, from Table 3, we can conclude that after the outbreak of the financial crisis in late 2008 and entering of the economy in recession, with the realization of negative GDP growth rates in the following 2009, all countries in the sample experienced significant increases in percentage share of NPLs in total loans. As during the observed period there was no significant recovery of economic activity in any of these countries, the share of NPLs in total loans continued to grow.

Since the loans granted to the corporate sector, i.e. to legal entities, are above-average risky and that they contribute substantially to the growth of share of NPLs in total loans of the banking sector, as well as that the loans granted to the retail sector carry a lower level of risk and that as such they are a priori acceptable to the bank, it is necessary to perform a comparative analysis of data on the movement of the share of NPLs in total disbursed loans by sectors in the banking systems of selected countries (see Table 4). 
Table 4

Review of the Share of NPLs in Total Loans by Sectors in Selected Countries in the Period 2010-2015

\begin{tabular}{|c|c|c|c|c|c|c|c|c|}
\hline \multirow{2}{*}{$\begin{array}{l}\text { Year/ } \\
\text { Country/ } \\
\text { Sector }\end{array}$} & \multicolumn{2}{|c|}{ Serbia } & \multicolumn{2}{|c|}{ Croatia } & \multicolumn{2}{|c|}{ Macedonia } & \multicolumn{2}{|c|}{ Bosnia and Herzegovina } \\
\hline & $\begin{array}{l}\text { Corporate } \\
\text { (in } \%)\end{array}$ & Retail (in \%) & $\begin{array}{l}\text { Corporate } \\
\text { (in } \% \text { ) }\end{array}$ & Retail (in \%) & $\begin{array}{l}\text { Corporate } \\
\text { (in } \% \text { ) }\end{array}$ & Retail (in \%) & $\begin{array}{l}\text { Corporate } \\
\text { (in } \% \text { ) }\end{array}$ & Retail (in \%) \\
\hline 2010 & 21.8 & 8.8 & 18.15 & 7.81 & 10.00 & 8.10 & 14.92 & 7.19 \\
\hline 2011 & 24.6 & 9.1 & 20.33 & 8.61 & 11.40 & 7.50 & 12.45 & 11.02 \\
\hline 2012 & 21.2 & 10.1 & 24.96 & 9.49 & 12.90 & 7.10 & 15.30 & 11.16 \\
\hline 2013 & 24.5 & 10.8 & 28.28 & 11.13 & 15.20 & 6.40 & 18.60 & 10.78 \\
\hline 2014 & 24.6 & 11.4 & 30.78 & 12.03 & 15.30 & 5.90 & 17.58 & 10.20 \\
\hline 2015 & 21.7 & 11.7 & 31.11 & 12.18 & 15.20 & 5.20 & 17.23 & 9.72 \\
\hline
\end{tabular}

Note. Source: Authors' review based on data taken from the websites of the central banks of analyzed countries.

Based on the analysis of the presented data, it can be concluded that during the whole period from 2010 to 2015, in all analyzed countries, the corporate sector recorded considerably higher NPL indicators in comparison to the retail sector. With this, it was analytically shown that the loans granted to the corporate sector, i.e. to legal entities, are above-average risky and that they contribute substantially to the growth of the share of NPLs in total loans of the banking sector, as well as that the loans granted to the retail sector carry a lower level of risk and that as such they are a priori acceptable to the bank. The highest NPL indicators in both analyzed sectors, compared to other countries, are found in the Republic of Croatia where at the end of the observed period almost one in three loans granted to the corporate sector was an NPL, while in the retail sector, this was the case with every tenth loan granted to this sector. In the Republic of Serbia at the end of the observed period, the NPL indicator of the corporate sector amounted to $21.7 \%$, which meant that one in five loans granted to the corporate sector was an NPL. NPL indicator of the retail sector in Serbia amounted to 11.7\%, which meant that one in ten loans granted to the retail sector was an NPL. In Bosnia and Herzegovina, share of NPLs granted to the corporate sector in total disbursed loans to this sector at end of the observed period amounted to $17.23 \%$, and of the retail sector $9.72 \%$. This meant that one in six loans disbursed to the corporate sector in Bosnia and Herzegovina was an NPL, while this was the case with every tenth loan disbursed to the retail sector. In the Republic of Macedonia, in this particular case, we also have a favorable situation compared to other countries analyzed, where the NPL indicator of the corporate sector at the end of the observed period amounted to $15.20 \%$ and of the retail sector only $5.20 \%$. This meant that at the end of the observed period, one in six loans disbursed to the corporate sector in Macedonia was an NPL, while this was the case with only one in twenty loans disbursed to the retail sector.

\section{Discussions}

The circumstances which were present before the financial crisis in the observed countries, in the form of high credit growth, followed by the debt crisis in the European Union, had a significant impact on the deterioration of the quality of the loan portfolio in their banking systems. However, although the trend of deterioration of NPLs has continued, or perhaps somewhere partially stopped, its intensity and effects vary from country to country. The Republic of Croatia has particularly significant negative effects and the greatest deterioration of NPLs, mostly because of the structure of the credit growth before the financial crisis. The analysis of the quality of the loan portfolio of the banking sector in the Republic of Serbia shows that a large part of NPLs emerged as a result of excessive risk-taking by banks in the period before 2008, when the share of 
NPLs in total loans amounted even to $11.30 \%$. However, the prolonged recession in the European Union, through reduced demand, had an impact on exports and the creditworthiness of exporters, had a decline in economic activity i.e. GDP, and had a negative impact on the corporate sector. Also, as a result of a prolonged recession, high unemployment caused the deterioration primarily in consumer loans, overdrafts, and credit cards. Macedonian banking sector was the least affected by the financial crisis compared to other analyzed countries, however, the trend of deterioration in the quality of the loan portfolio was significant, with a slight improvement of the situation in recent years. The fact is that the reduction in GDP was proportionally lower than in the rest of the countries in the sample, so consequently a negative impact on the quality of the loan portfolio was also smaller. The banking sector in Bosnia and Herzegovina was not directly affected by the financial crisis, primarily because Bosnia and Herzegovina did not invest in high-risk securities because of formal restrictions, and partly because of the lack of potential for it. However, the indirect effects of the crisis are also expressed in the form of the decline in economic activity, stricter loan conditions, and growth of interest rates, which resulted in difficulty to service loan debts and in the deterioration of the quality of loan portfolio, and in the following years, slower growth of the real sector and investing. The banking sectors of Serbia, Croatia, and Bosnia and Herzegovina have experienced more adverse consequences of the financial crisis than the banking sector of Macedonia. The reduction of GDP is of course associated with the macroeconomic policy. The Republic of Macedonia was low indebted country before the crisis, and creators of the macroeconomic policy used this to increase the debt during the crisis in order to better redeem its negative effects.

\section{Conclusions and Implication}

The research has shown that in the conditions of recession and financial crisis, in the observed period from 2008 to the end of 2015, the percentage share of NPLs in total loans is growing, both in the banking system of the Republic of Serbia and in the banking systems of the analyzed countries of the South-Western Balkans. Also, in the analysis of the sectorial structure of NPLs by countries, it is noted in each of them that the corporate sector considered as a whole generates above-average amounts and percentages of non-performing bank loans, while the retail sector in contrast has a lower percentage share of NPLs in total loans granted to this sector.

The main challenge for all four countries in the future is how to stimulate further economic growth. If there is no increase in lending, first of all in the corporate sector, it will inevitably lead to a further deterioration of the quality of its loan portfolio. With some delay, the quality of the loan portfolio of the retail sector will also deteriorate. Also, intensification of efforts and creation of incentives to address the issue of NPLs remains one of the main challenges.

\section{References}

Barisitz, S. (2011). Nonperforming loans and CESE-What do they comprise? Focus on European Economic Integration, Q4/11, Österreichische Nationalbank, Vienna.

Central Bank of Bosnia and Herzegovina. (2016). Financial stability report 2015. Sarajevo, Bosnia and Herzegodina.

Croatian National Bank. (2016a). Annual report 2015. Zagreb, Croatia.

Croatian National Bank. (2016b). Banks bulletin no. 29. Zagreb, Croatia.

Decision on Bank Reporting. Official Gazette of the Republic of Serbia, no.125/2014, 4/2015, 111/2015, 61/2016, and 69/2016.

Decision on Classification of Bank Balance Sheet Assets and Off-balance Sheet Items. Official Gazette of the Republic of Serbia, no. $94 / 11,57 / 12,123 / 12,43 / 13,113 / 13,135 / 14,25 / 15,38 / 15,61 / 16$, and 69/16. 
Klein, N. (2013). Non-performing loans in CEESE: Determinants and impact on macroeconomic performance. IMF Working Paper 13/72.

Mirkovic, V. (2013). Solving the issue of bad debts as an essential factor of stability of the banking system. Ekonomski vidici, Belgrade.

National Bank of Macedonia. (2012). Report on the banking system of the Republic of Macedonia in 2011, annex no. 6: The structure of loans to non-financial entities. Skoplje, Macedonia.

National Bank of Macedonia. (2014). Report on the risks of the banking system of the Republic of Macedonia in 2013, annex no. 6: The structure of loans to non-financial entities; annex no. 24: The indicators of the risk level of credit exposure to the sector of non-financial companies and others; and annex no. 25: The indicators of the risk level of credit exposure to the retail sector. Skoplje, Macedonia.

National Bank of Macedonia. (2016a). Report on financial stability in the Republic of Macedonia for 2015, annex no. 16: The indicators of financial stability of the banking system of the Republic of Macedonia, 2005-2015. Skoplje, Macedonia.

National Bank of Macedonia. (2016b). Report on the risks of the banking system of the Republic of Macedonia in 2015, annex no. 6: The structure of loans to non-financial entities; annex no. 25: The indicators of the risk level of credit exposure to the sector non-financial companies and others; and annex no. 26: The indicators of the risk level of credit exposure to the retail sector. Skoplje, Macedonia.

National Bank of Serbia. (2011). Control of operations of banks, report for the fourth quarter of 2010. Belgrade, Serbia.

National Bank of Serbia. (2012). Control of operations of banks, report for the fourth quarter of 2011. Belgrade, Serbia.

National Bank of Serbia. (2013). The banking sector in Serbia, report for the fourth quarter of 2012. Belgrade, Serbia.

National Bank of Serbia. (2014) The banking sector in Serbia, report for the fourth quarter of 2013. Belgrade, Serbia.

National Bank of Serbia. (2015). The banking sector in Serbia, report for the fourth quarter of 2014. Belgrade, Serbia.

National Bank of Serbia. (2016a). Annual report on the stability of the financial system in 2015. Belgrade, Serbia.

National Bank of Serbia. (2016b). The banking sector in Serbia, report for the fourth quarter of 2015. Belgrade, Serbia.

Zelenovic, V., \& Macut, M. (2016). The problem of non-performing loans in Serbia with regard to the neighboring countries. Ekonbiz Bijeljina. 